\title{
Interpreting last glacial to Holocene dust changes at Talos Dome (East Antarctica): implications for atmospheric variations from regional to hemispheric scales
}

\author{
S. Albani ${ }^{1,2}$, B. Delmonte ${ }^{1}$, V. Maggi ${ }^{1}$, C. Baroni ${ }^{3}$, J.-R. Petit ${ }^{4}$, B. Stenni ${ }^{5}$, C. Mazzola ${ }^{1}$, and M. Frezzotti ${ }^{6}$ \\ ${ }^{1}$ Department of Environmental Sciences, University of Milano-Bicocca, Milan, Italy \\ ${ }^{2}$ Graduate School in Polar Sciences, University of Siena, Siena, Italy \\ ${ }^{3}$ Dipartimento di Scienze della Terra, Università di Pisa, Pisa, Italy \\ ${ }^{4}$ LGGE-CNRS Université Joseph Fourier-Grenoble, Grenoble, France \\ ${ }^{5}$ Dipartimento di Geoscienze, Università di Trieste, Trieste, Italy \\ ${ }^{6}$ ENEA-UTA, Roma, Italy
}

Correspondence to: S. Albani (samuel.albani@unimib.it)

Received: 20 December 2011 - Published in Clim. Past Discuss.: 5 January 2012

Revised: 20 March 2012 - Accepted: 22 March 2012 - Published: 4 April 2012

\begin{abstract}
Central East Antarctic ice cores preserve stratigraphic records of mineral dust originating from remote sources in the Southern Hemisphere, and represent useful indicators of climatic variations on glacial-interglacial time scales. The peripheries of the East Antarctic Ice Sheet, where ice-free areas with the potential to emit dust exist, have been less explored from this point of view. Here, we present a new profile of dust deposition flux and grain size distributions from an ice core drilled at Talos Dome (TALDICE, Northern Victoria Land, East Antarctica), where there is a significant input of dust from proximal Antarctic ice-free areas. We analyze dust and stable water isotopes variations from the Last Glacial Maximum to the Late Holocene, and compare them to the EPICA Dome C profiles from central East Antarctica. The smaller glacial-interglacial variations at Talos Dome compared to Dome $\mathrm{C}$ and a distinctive decreasing trend during the Holocene characterize the TALDICE dust profile. By deciphering the composite dust signal from both remote and local sources, we show the potential of this combined proxy of source activity and atmospheric transport to give information on both regional and larger spatial scales. In particular, we show how a regional signal, which we relate to the deglaciation history of the Ross Sea embayment, can be superimposed to the broader scale glacial-interglacial variability that characterizes other Antarctic sites.
\end{abstract}

\section{Introduction}

Mineral dust is an active component of the climate system, interacting directly and indirectly with solar radiation, clouds and biogeochemistry (IPCC, 2007). It is emitted by the action of wind stress on arid or semiarid areas, with low vegetation cover and the capacity of accumulating fine-grained material (Prospero et al., 2002); as such, dust source areas may vary both in terms of activity and geographical location or in size in response to environmental changes. Once entrained in the atmosphere, small dust grains can be transported over large distances by winds before they are deposited on the surface (Prospero et al., 2002). In environmental settings where formation and preservation of a continuous and undisturbed stratigraphy is likely, mineral dust represents a proxy for past climate, atmospheric and environmental changes (Kohfeld and Harrison, 2001).

Ice cores are invaluable climate archives (EPICA Community Members, 2004; Steffensen et al., 2008). Dust records from ice cores have been produced from both low-latitude ice caps (Thompson et al., 1995; Xu et al., 2010) and polar ice sheets (Petit et al., 1999; Lambert et al., 2008), preserving information on past variability of the dust cycle. In particular, dust records from polar ice cores have been shown to be very reliable indicators of climate variability on glacialinterglacial time scales (Fuhrer et al., 1999; Lambert et al., 2008). Most of the more detailed information on dust deposition in Antarctica on glacial-interglacial time scales stems from ice cores drilled in the Central East Antarctic Plateau 
(CEAP), e.g. Vostok (Petit et al., 1999) and EPICA Dome C (EDC) (Lambert et al., 2008). All sites from CEAP can be considered rather homogeneous in terms of snow accumulation rates, dust depositional fluxes, glacial-interglacial ratio of dust deposition and remote dust sources (Delmonte et al., 2004, 2008). On the other hand, the peripheries of the East Antarctic Ice Sheet are still poorly explored from this point of view (Delmonte et al., 2010b; Bory et al., 2010).

We present here a new mineral dust record spanning the period from 2 to $23 \mathrm{kyr}$ Before Present (before $1950 \mathrm{AD}$; $\mathrm{BP})$, obtained from the TALos Dome Ice CorE drilling project (TALDICE). Talos Dome $\left(159^{\circ} 11^{\prime} \mathrm{E}, 72^{\circ} 49^{\prime} \mathrm{S}\right.$, 2315 ma.s.l., Fig. 1) is a peripheral dome located in the South Pacific/Ross Sea sector of the East Antarctic Plateau (www.taldice.org). The uppermost $1550 \mathrm{~m}$ of the $1620 \mathrm{~m}$ deep TALDICE ice core provides an undisturbed record of paleoclimate for the Ross Sea sector of East Antarctica, covering the past $250000 \mathrm{yr}$ (Stenni et al., 2011). The geographic location of the drilling site, with relatively high snow accumulation rates $\left(80 \mathrm{~kg} \mathrm{~m}^{-2} \mathrm{yr}^{-1}\right.$, average 2004$1259 \mathrm{AD}$ ), enables accurate dating of the core, particularly during the last climatic transition (Buiron et al., 2011). The site also provides a good relative chronological link with other relevant Antarctic and Greenland ice cores (LemieuxDudon et al., 2010).

The climatic history of TALDICE was depicted by stable water isotopes $\left(\delta^{18} \mathrm{O}\right)$ profiles, in comparison with other Antarctic sites. Some differences highlighted Talos Dome's more "coastal" behaviour compared to sites from CEAP, with distinctive features reflecting changes in local elevation and/or in moisture source and pathways linked to the retreat of the Ross Ice Shelf/Ice Sheet and thinning of the peripheries of the East Antarctic Ice Sheet during the deglaciation (Stenni et al., 2011; Masson-Delmotte et al., 2011).

Previous work has shown that dust deposition at TALDICE responded to large climate variations on glacialinterglacial time scales, similar to the CEAP sites, with higher fluxes during cold stages (Delmonte et al., 2010b), when TALDICE and CEAP sites had a similar dust isotopic composition, suggesting common dust sources (Delmonte et al., 2010a). On the other hand, a different dust isotopic composition between TALDICE and CEAP sites during the Holocene, together with the presence of dust grains larger than $5 \mu \mathrm{m}$ (diameter) that were virtually absent in the EDC core, highlight the significant contribution of dust of local origins to the TALDICE dust content (Delmonte et al., 2010b). The likely candidates to act as local dust sources are the widespread high-elevation ice-free areas of Northern Victoria Land (Delmonte et al., 2010b).

In this work, we present and analyze a higher resolution dust record, and in light of previous works (Delmonte et al., 2010a, b), we carry out a closer inspection of dust flux and grain size variability with respect to the TALDICE stable water isotopes $\left(\delta^{18} \mathrm{O}\right)$ profile, and compare this profile to EDC, which is assumed to be representative of CEAP sites. In this

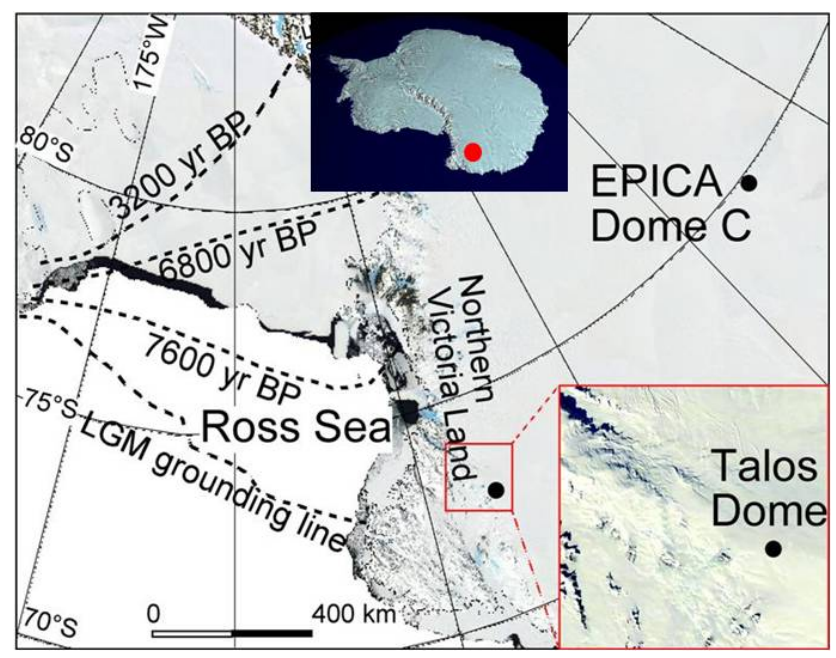

Fig. 1. Satellite image (Landsat Image Mosaic of Antarctica Project) of the Ross Sea and Dome C area. The top insert shows the approximate location of Talos Dome (red dot) in Antarctica (A RADARSAT Map of Antarctica. Credit: AMM, SVS, NASA, CSA. Source: http://apod.nasa.gov/apod/ap991116.html). The insert on the bottom-right side shows the Talos Dome area. Dashed lines with accompanying time indication show the timing of the Ross Ice Shelf grounding line retreat (Conway et al., 1999; Hall, 2009).

comparative dust- $\delta^{18} \mathrm{O}$ Talos Dome versus CEAP analysis throughout the deglaciation and the Holocene, we explore possible links between dust sources, atmospheric variations and the deglaciation history of the Ross Sea embayment.

\section{Analytical methods}

In this work, we present $\sim 550$ discrete $(25 \mathrm{~cm}$ long) ice sections in the $175-870 \mathrm{~m}$ depth range, corresponding to the $\sim 2-23$ kyr BP time period (Buiron et al., 2011), with an average time resolution of one sample every $\sim 30 \mathrm{yr}$ for the Holocene (average sample time span $\sim 5 \mathrm{yr}$ ) and the deglaciation and one sample every $\sim 350 \mathrm{yr}$ for the LGM (average sample time span $\sim 23 \mathrm{yr}$ ). Samples were decontaminated in a clean room (class 1000) under a laminar flow bench (class 100) following the procedure adopted in Delmonte et al. (2004, 2010b). Post-melt samples were settled for $24 \mathrm{~h}$ and then analyzed for their insoluble mineral dust concentration and size. This was done to avoid the counting of metastable compounds that may be still in the solution immediately after melting (Sala et al., 2008). The analyses of dust concentration (number and volume) and size were performed at the University of Milano-Bicocca using a Beckman Coulter-Multisizer ${ }^{\mathrm{TM}} 3$ Coulter Counter ${ }^{\circledR}$, with three replicate measurements for each sample. The size range of the measurements was $1-30 \mu \mathrm{m}$. Mass concentration was calculated assuming a $2.5 \mathrm{~g} \mathrm{~cm}^{-3}$ of particle density (e.g. Petit et al., 1999). The dust concentration profile was then 
compared for inter-laboratory calibration with measurements from the LGGE in Grenoble (Delmonte et al., 2010b). We compared our set of samples against a set of 150 blanks, in terms of number concentration by applying a 1-tailed t-test $(\alpha=0.05)$. The results for the $1-5 \mu \mathrm{m}$ and the 5-10 $\mu \mathrm{m}$ range indicate that $100 \%$ and $\sim 95 \%$ of the samples were significantly higher than the blanks, with an average signal-tonoise ratio of 40 and 15 , respectively. We then calculated the measurement uncertainties, defined as the ratio between the standard deviation of the mean and the mean from the three replicates, and expressed them as percentages. The 90th percentile of uncertainties is $5 \%$ and $10 \%$ for the $1-5 \mu \mathrm{m}$ and the 5-10 $\mu \mathrm{m}$ range, respectively. A fine particles percentage (FPP) metric was used to describe dust size distributions, following Delmonte et al. (2004). The age profiles were based on the TALDICE-1 timescale (chronological uncertainties: $\pm 300 \mathrm{yr}$ from 8 to $15 \mathrm{kyr} \mathrm{BP}, \pm 500 \mathrm{yr}$ back to $17.5 \mathrm{kyr}$ and up to \pm 1500 yr during the Last Glacial Maximum, LGM) (Buiron et al., 2011). Dust depositional fluxes were calculated as dust concentration (mg dust per $\mathrm{kg}$ of ice/firn), multiplied by the ice/snow accumulation rate $\left(\mathrm{kg} \mathrm{m}^{-2} \mathrm{yr}^{-1}\right)$ from Buiron et al. (2011).

\section{The TALDICE dust profile: main features}

Typical examples of dust measurements from the TALDICE ice core are shown in Fig. 2. Generally speaking, the mass (volume) size distributions of dust in the TALDICE samples ( $<5 \mu \mathrm{m}$ size range) are characterized by a poor size sorting during the current interglacial period (Fig. 2a), but shaped as log-normal distributions with a variable modal value around $2 \mu \mathrm{m}$ during the LGM (Fig. 2b). In addition, particles in the 5-10 $\mu \mathrm{m}$ range are present in significant amounts in our samples, in contrast with CEAP sites, where they are virtually absent (Delmonte et al., 2004). These findings confirm the preliminary results from Delmonte et al. (2010b) for Talos Dome. Similarly, the presence of particles larger than $5 \mu \mathrm{m}$ of possible local origin has been observed on Berkner Island, in the Weddell Sea sector of Antarctica, in opposition to the more inland and high elevation site of EPICA Dronning Maud Land (Bory et al., 2010).

The main features of the TALDICE dust profile are shown in Fig. 3, together with the $\delta^{18} \mathrm{O}$ profile (Fig. 3a), a proxy of local temperature at the Talos Dome site (Stenni et al., 2011). Both the dust mass concentration (Fig. 3b) and the depositional flux profiles (Fig. 3c) $(1-5 \mu \mathrm{m}$ size range) show large variability associated with glacial-interglacial changes, confirming the preliminary results from Delmonte et al. (2010b). Dust concentration measurements were compared with the set of samples analyzed in Grenoble (Delmonte et al., 2010b), which show a similar pattern and absolute values (Fig. 3b). Comparison of concentration and flux profile trends provides a mechanism to check whether changes in accumulation rates are the sole controlling factor
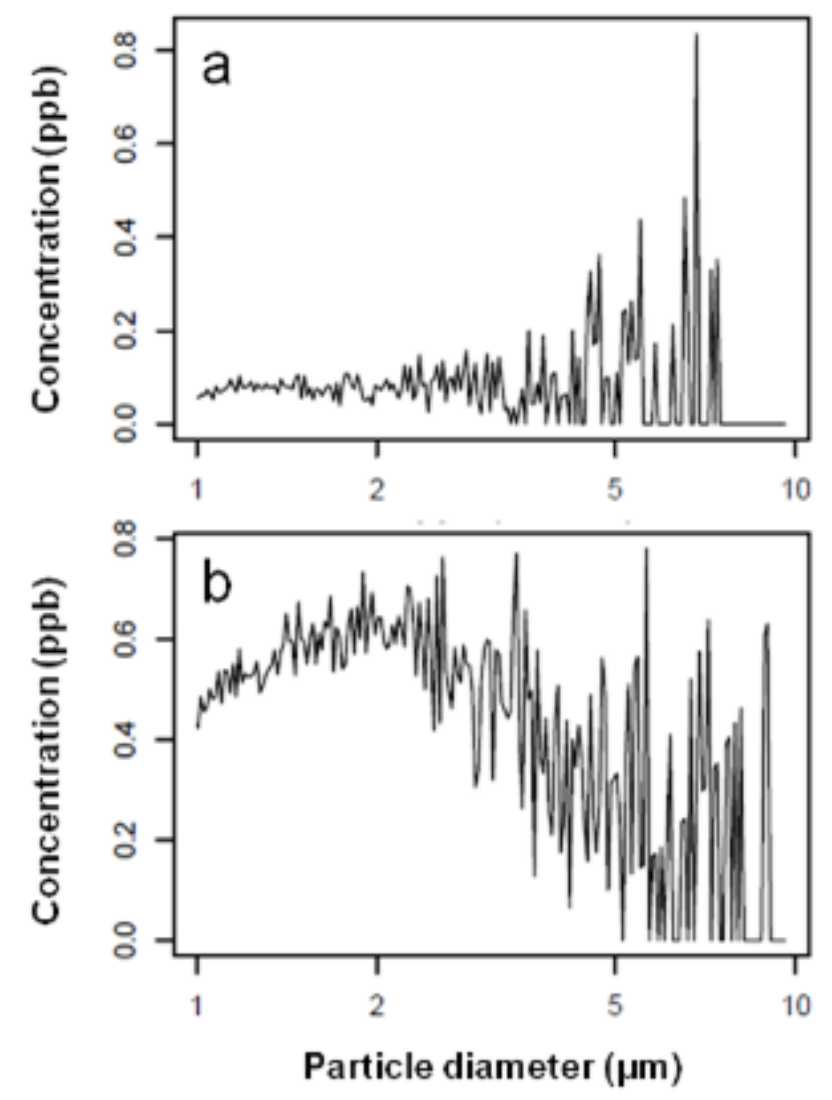

Fig. 2. Examples of dust size distributions from TALDICE ice core samples. (a) Late Holocene sample at $210.25 \mathrm{~m}$ depth. (b) Glacial sample at $802.00 \mathrm{~m}$ depth.

(see the definition of flux in Sect. 2). Here, this is not the case (cf. Fig. 3b and c). Flux, which represents the absolute deposition rate at the site and allows for direct comparison with other sites, will be discussed instead of the concentration profile throughout the rest of the paper.

Both the 5-10 $\mu \mathrm{m}$ dust flux profile (Fig. 3d) and the finer fraction $(1-5 \mu \mathrm{m})$ clearly show the main climate transitions, although the magnitude of the variation of the coarse fraction is characterized by only minor changes on the glacialinterglacial time scale. The $5-10 \mu \mathrm{m}$ size fraction accounts for $\sim 8 \%$ of the total mass in the $1-10 \mu \mathrm{m}$ range during the LGM, and $\sim 21-25 \%$ in the Holocene, on average.

Following Delmonte et al. (2004) we plotted the FPP parameter (Fig. 3e), which shows a larger relative abundance of finer particles during the LGM compared to the Holocene. This pattern is qualitatively similar to that of EDC (Delmonte et al., 2004; Lambert et al., 2008), but a direct comparison is complicated by the presence of dust from local sources in TALDICE (Delmonte et al., 2010b). While for the 5$10 \mu \mathrm{m}$ size fraction we may assume that all of the dust is from local sources (Delmonte et al., 2010b), it seems reasonable to consider dust in the $1-5 \mu \mathrm{m}$ fraction as a mixture 


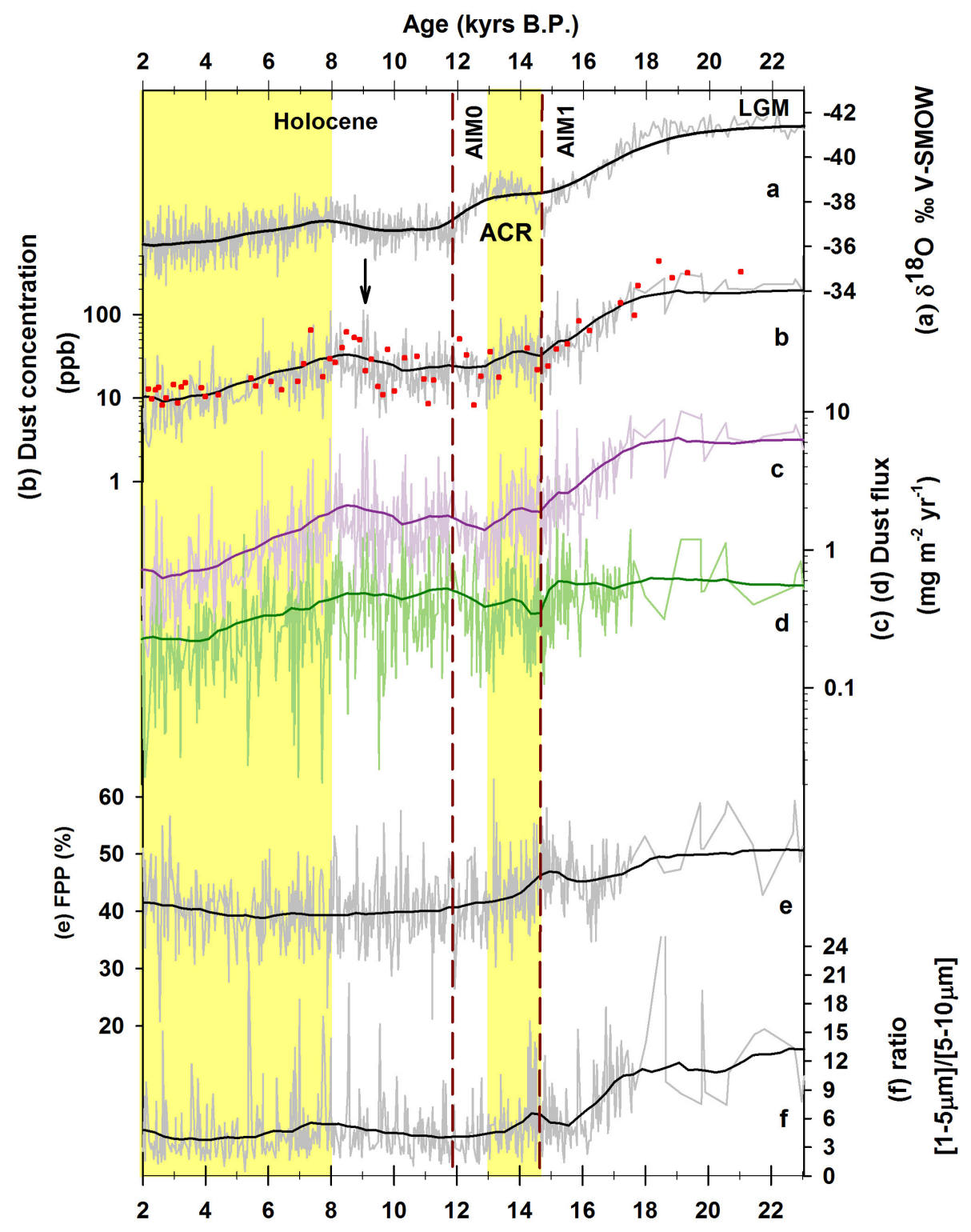

Fig. 3. TALDICE records : (a) $\delta^{18} \mathrm{O} \%$ V-SMOW (Stenni et al., 2011) plotted on a reversed axis; (b) dust concentration (ppb) in the [1-5] $\mu \mathrm{m}$ size range (grey line: Milano; red dots: Grenoble; Delmonte et al., 2010b); (c) dust flux $\left(\mathrm{mg} \mathrm{m}^{-2} \mathrm{yr}^{-1}\right.$ ) in the [1-5] $\mu \mathrm{m}$ size range (purple line); (d) dust flux $\left(\mathrm{mg} \mathrm{m}^{-2} \mathrm{yr}^{-1}\right)$ in the [5-10] $\mu \mathrm{m}$ size range (green line); (e) FPP (\%), defined as the [1-2]/[1-5] $\mu \mathrm{m}$ ratio (Delmonte et al., 2004); (f) ratio between the mass (volume) of particles in the $1-5 \mu \mathrm{m}$ and 5-10 $\mu \mathrm{m}$ size intervals. Thin lines represent the original data, and superimposed thick lines mark the smoothed profiles (negative exponential with sampling proportion 0.1). The vertical dashed lines mark the AIM0 and AIM1 events. The arrow in (b) marks the Holocene dust maximum. Background yellow bands highlight features of the dust record described in the text: the Holocene decreasing trend (left) and the ACR (right).

of particles from both local and remote sources, with unknown relative proportions, in principle. In addition, some recent analyses (Delmonte et al., 2012) by SEM-EDS on TALDICE Holocene dust samples show ubiquitous presence of volcanic material mixed with dust, even in the very low-concentrated background samples. Narcisi et al. (2010) pointed out the presence of 16 visible tephra layers of "local" origin (Antarctica) during the Holocene in the TALDICE record. While in terms of the insoluble particles flux this is a minor contribution that does not alter significantly the absolute values and the interpretations of our records (which do not include visible tephra layers), this obviously limits the possibility to use the $\mathrm{Sr}$ and $\mathrm{Nd}$ isotopic fingerprint of "bulk" dust extracted from the samples. Complementary to FPP, we use the $[1-5 \mu \mathrm{m}] /[5-10 \mu \mathrm{m}]$ size metric, which also shows a larger relative abundance of finer particles in the LGMHolocene comparison (Fig. 3f). 
A closer inspection of the dust profiles $(1-5 \mu \mathrm{m})$ reveals that after the LGM, during the first stage of the deglaciation, which started almost synchronously all over Antarctica at $18.2 \pm 0.7 \mathrm{kyr}$ BP (Termination I) (Stenni et al., 2011) (Fig. 4a, c), the TALDICE dust flux (Fig. 4b) shows a drop in its absolute values with a decreasing trend at a rate of $2.2 \mathrm{mg} \mathrm{m}^{-2} \mathrm{yr}^{-1}$ per kyr until the onset of the Antarctic Cold Reversal (ACR). Two events known as the Antarctic Isotope Maxima (AIM1: $14.7 \pm 0.3 \mathrm{kyr} \mathrm{BP}$ and AIM0: $11.9 \pm 0.1 \mathrm{kyr} B$ ) (Stenni et al., 2011) bracket the ACR temperature reversal. After reaching a relative minimum at AIM1, which can be identified despite the high scatter of the data, the TALDICE dust flux (Fig. 4b) increases synchronously with the $\delta^{18} \mathrm{O}$ decline during the ACR (Fig. 4a). After a relative maximum in dust flux, the timing of the declining dust trend from $13.4 \pm 0.4 \mathrm{BP}$ and the following minimum $(13.0 \pm 0.4 \mathrm{kyr} \mathrm{BP})$ lead respectively the $\delta^{18} \mathrm{O}$ ACR/AIM0 transition $(12.7 \pm 0.4)$ and AIM0 $(11.9 \pm 0.1 \mathrm{kyr}$ BP) (Stenni et al., 2011). The early Holocene is characterized by large variability in the dust flux at Talos Dome, with a maximum deposition at $\sim 9 \mathrm{kyr}$ BP. However, neither the dust flux (Fig. 4b), nor the $\delta^{18} \mathrm{O}$ (Fig. 4a) show linear trends. The main feature of the record during mid-Holocene is a clear declining trend in dust flux from $\sim 8 \mathrm{kyr}$ BP, which persists during the late Holocene, at least for the period spanned by our data (Fig. 4b). This feature appears to occur in parallel with an increasing trend in $\delta^{18} \mathrm{O}$ (Fig. 4a).

\section{Discussion}

The starting point of our discussion is the contribution of dust from both remote and local sources to TALDICE. First, we will examine the TALDICE dust- $\delta^{18} \mathrm{O}$ relationship and its time evolution in comparison with EDC (and by extension the CEAP), assumed to represent the remote dust endmember, and we will try to isolate the two superposed signals of remote and proximal dust deposition (Sect. 4.1). Finally, we will explore the relationship between the variations in the remote and local dust inputs to Talos Dome and climate and atmospheric changes (Sect. 4.2).

\subsection{Comparing TALDICE and Central East Antarctic Plateau}

We can directly compare the time evolution of the dust flux at Talos Dome (1-5 $\mu \mathrm{m})$ with EDC (and the CEAP) (Fig. 4b), and examine this in conjunction with the temperature history of both sites, as depicted by the $\delta^{18} \mathrm{O}$ profiles (Fig. 4a and $\mathrm{c}$, respectively). Both sites show a decrease in dust deposition fluxes on the glacial-interglacial time scale, but the absolute values (Table 1) - and the amplitude of these variations - are different: the LGM to Holocene flux ratio is $\sim 22$ for EDC and in general for CEAP, but $\sim 4$ to $\sim 10$ for

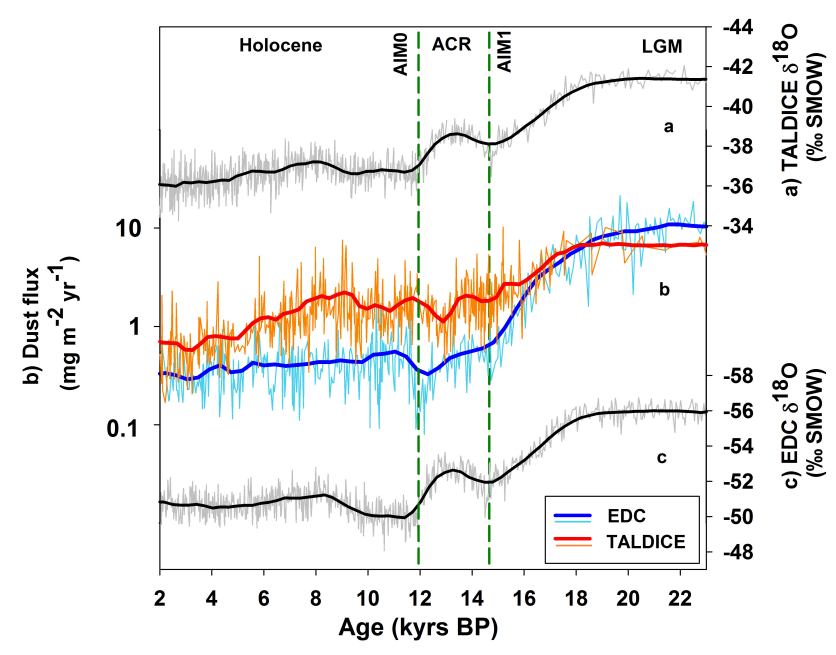

Fig. 4. Comparison of TALDICE and EDC dust fluxes $(1-5 \mu \mathrm{m})$ and $\delta{ }^{18} \mathrm{O}$ profiles. (a) TALDICE $\delta^{18} \mathrm{O} \%$ V-SMOW (Stenni et al., 2011) plotted on a reversed axis. (b) Age profiles of EDC flux (light blue line) and TALDICE flux (orange line). Superimposed thick lines are the smoothed profiles of EDC (dark blue) and TALDICE (red), respectively. (c) EDC $\delta^{18} \mathrm{O} \%$ V-SMOW (Stenni et al., 2010) plotted on a reversed axis. EDC dust (Delmonte et al., 2005) and $\delta^{18} \mathrm{O}$ (Stenni et al., 2010) data are plotted using the new age scale by Lemieux-Dudon et al. (2010). Thin lines represent the original data, and superimposed thick lines mark the smoothed profiles (negative exponential with sampling proportion 0.05 ).

TALDICE when the Early and the Late Holocene are considered, respectively. This should not be surprising, considering the fact that local sources contribute dust to TALDICE, but not to EDC (Delmonte et al., 2010b). Thus, the temporal variability of the contributions from local and remote dust sources at Talos Dome may explain the differences in magnitude and temporal patterns, with respect to the EDC dust flux, which is derived exclusively from remote sources (Delmonte et al., 2008) and can be considered representative of dust deposition from remote sources on glacial-interglacial time scales for a broad area (Lambert et al., 2008; Mahowald et al., 2010).

While the dust isotopic composition indicates Southern South America as the primary dust source during glacial periods for both EDC and TALDICE (Delmonte et al., 2010a), a possible contribution of Australia as a secondary, but significant dust source to the Talos Dome area - more than for the CEAP - is suggested by climate models, although those do not account for Antarctic sources ( $\mathrm{Li}$ et al., 2008; Albani et al., 2011). Given the predominant contribution of local dust to the geochemical fingerprint of TALDICE, it is not possible to directly test this hypothesis (Delmonte et al., 2010b), nor to assess if time-varying relative contributions from remote sources during the Holocene differentiate EDC and TALDICE dust deposition. 
Table 1. Average dust deposition flux $\left(\mathrm{mg} \mathrm{m}^{-2} \mathrm{yr}^{-1}\right)$ for TALDICE (this work) and EDC (Delmonte et al., 2004) in three different sub-periods of the temporal window analysed in the text.

\begin{tabular}{lrr}
\hline Period & $\begin{array}{r}\text { TALDICE } \\
\text { flux }(1-5 \mu \mathrm{m})\end{array}$ & EDC flux \\
\hline Late Holocene (2-5 kyr BP) & 0.70 & 0.33 \\
Early Holocene (8-11.7 kyr BP) & 1.84 & 0.47 \\
LGM (18-23 kyr BP) & 7.24 & 9.49 \\
\hline
\end{tabular}

During the LGM, the dust flux is apparently lower at TALDICE compared to EDC. At this time, dust at Talos Dome is thought to be derived mainly from remote areas (Delmonte et al., 2010a). This apparent difference in the magnitude of the deposition at the two sites, at a time when they are characterized by a common geochemical fingerprint (Delmonte et al., 2010a), may be explained either by (1) a bias in TALDICE data related to the limited number of samples analyzed so far for the glacial period, compared to the large variability of the data during LGM, and/or (2) a relative dating error between the two sites for this time interval, influencing accumulation rates and dust fluxes, and/or (3) a real difference in dust flux from remote areas related to geographic position and atmospheric circulation. We will not discuss this further as this does not affect our interpretations and is beyond the scope of this paper.

During Termination I (18.2 $\pm 0.7 \mathrm{kyr}$ BP) both TALDICE and EDC dust flux records show a decreasing trend, similar both in terms of magnitude and rate of decrease (Fig. 4b), at the time of the drop in dust advection from remote sources (Delmonte et al., 2010a). After $\sim 16 \mathrm{kyr}$ BP the dust flux magnitudes and patterns clearly diverge, whereas the $\delta^{18} \mathrm{O}$ patterns at TALDICE and EDC coherently evolve until $\sim 12.5-12.7 \mathrm{kyr}$ BP (the different absolute values of $\delta^{18} \mathrm{O}$ reflect the different temperatures at the two sites) (Stenni et al., 2011). An apparent re-alignment of dust flux patterns occurs in correspondence with the onset of the ACR (Fig. 4b). The $\delta^{18} \mathrm{O}$ profiles occur in parallel with the onset and termination of the ACR at TALDICE and EDC (Fig. 4a, c). While the EDC dust flux and $\delta^{18} \mathrm{O}$ follow the same pattern, dust deposition at Talos Dome has different features: after $\sim 13.5-$ $13.7 \mathrm{kyr}$ BP the two profiles are definitively different, with an early relative dust minimum at TALDICE around $13 \mathrm{kyr}$ BP, which is absent in central Antarctica. In addition, there is no evidence for the so-called "pre-Holocene dust minimum" (11.3-12.1 kyr BP), which has been found in different ice cores from central Antarctica, and was used for stratigraphic correlations (Delmonte et al., 2004). This difference may be explained by the presence of local dust deposition at Talos Dome, which probably masks a feature that can be related to the remote dust input based on our knowledge of the processes at EDC (Delmonte et al., 2004; Lambert et al., 2008). We have already described the TALDICE dust flux (Fig. 4b) and its apparent inverse correlation with the $\delta^{18} \mathrm{O}$ pattern (Fig. 4a) after $13 \mathrm{kyr}$ BP through the Holocene. At EDC, on the other hand, while the dust flux shows a quick recovery after the pre-Holocene dust minimum and then is characterized by a slight long-term Holocene decreasing trend (Delmonte et al., 2005) (Table 1), it does not seem to mimic the oscillations shown by the $\delta^{18} \mathrm{O}$ pattern. The EDC $\delta^{18} \mathrm{O}$ pattern is characterized by an early Holocene "optimum" with high values, followed by a relative minimum and then by a slight increase through the mid-Holocene (Fig. 4c). Overall, while both EDC and TALDICE dust show a declining trend during the mid/late Holocene, it is rather difficult to establish (based on our present data) if any closer correlation could be identified, mainly because of the data resolution and the lack of knowledge on the proportions of all the possible contributions of local and remote dust to Talos Dome.

As a summary, during cold periods, when dust input from remote sources is large and a climate coupling between the mid-to-high southern latitudes exists (Petit et al., 1999; Lambert et al., 2008; Albani et al., 2011), e.g. the end of the LGM and ACR, the patterns of dust deposition between TALDICE and EDC are more similar than for periods characterized by lower remote dust input, such as the end of the deglaciation and the Holocene. In addition, while the dust $-\delta^{18} \mathrm{O}$ relation at EDC seems to be closer on the glacial-interglacial time scale than within the Holocene, at TALDICE the Holocene similarity in dust and $\delta^{18} \mathrm{O}$ patterns is quite clear.

\subsection{Linking TALDICE dust profile with climate and atmospheric changes}

Understanding the factors controlling the variability of dust advection from local sources to Talos Dome is necessary in order to explain the whole TALDICE dust signal, as is the extent to which the regional atmospheric circulation modulates the variability of dust advection to Talos Dome. Work on water stable isotopes has shown how, when superimposed on variations in climate change patterns, differences in $\delta^{18} \mathrm{O}$ profiles among Antarctic ice cores can be understood if site-specific properties are considered (Stenni et al., 2011; Masson-Delmotte et al., 2011). During the Holocene, the dust and $\delta^{18} \mathrm{O}$ profiles at EDC do not vary proportionally, which is likely to be an expression of the remote nature of dust reaching the site, and indicative of changed conditions at the dust source areas and/or in the mid-to-high latitudes atmospheric connection (Lambert et al., 2008). The closer connection of dust and $\delta^{18} \mathrm{O}$ main trends at Talos Dome highlights the likely influence that local/regional changes had on the proximal dust contribution to the site. The main source of the differences between EDC and TALDICE $\delta^{18} \mathrm{O}$ profile can be related to the retreat of the Ross Ice Sheet (the grounded Ross Ice Shelf during the glacial period; Stenni et al., 2011). In the following we explore the possible drivers of variability in local dust sources and transport to the Talos Dome site. 
Potential proximal sources of dust for TALDICE include regoliths and Pleistocene glacial drifts located at high altitude in the Victoria Land. While some of these sources are known to have been active well beyond the Holocene and the LGM, some glacial sediments such as younger drifts became available during the last climatic cycle, and retreat moraines locally deposited during the deglaciation could have contributed dust after glacial maxima (Delmonte et al., 2010b and references therein). In the Talos Dome regional setting, the deglaciation (i.e. thinning of the grounded Ross Ice Sheet and retreat of its grounding line) started about $14 \mathrm{kyr} \mathrm{BP}$ at the Ross Ice Sheet margin, became widespread about $12 \mathrm{kyrBP}$, and was completed by about $8 \mathrm{kyrBP}$ at Terra Nova Bay (Baroni and Hall, 2004; Baroni et al., 2005). Afterwards, changes in the extension of the floating Ross Ice Shelf and sea ice continued throughout the Holocene (Hall, 2009).

Dust transported from remote sources generally reaches Antarctica through medium/high tropospheric pathways ( $\mathrm{Li}$ et al., 2008; Krinner et al., 2010; Albani et al., 2011), although transport mechanisms acting in a competitive way may be responsible for differences in coastal areas compared to high-elevation inland sites (Delmonte et al., 2004; Krinner et al., 2010; Bory et al., 2010). On the other hand, because Talos Dome is located inland with respect to the icefree source areas (Fig. 1), advection of air masses from the ocean is a necessary condition for the transport of local dust to the site. Presently, the Ross Sea sector around Terra Nova Bay is one of the most active areas of mesoscale cyclogenesis along the Antarctic coasts, particularly in the form of dry cyclogenesis, which near the Transantarctic Mountains can set up conditions for the development of barrier winds, generated by low-level blocking of air masses by the steep orographic barrier represented by the Transantarctic Mountains (Carrasco et al., 2003). Some sectors of the East Antarctic Ice Sheet facing the Southern Ocean receive moisture-laden air masses, leading to snowfall mainly during the winter from western pathways, while Victoria Land is highly affected by the peculiar conditions in the Ross Sea, with additional eastern pathways during summer moving inland from the Ross Sea (Scarchilli et al., 2011). We can thus consider the TALDICE $\delta^{18} \mathrm{O}$ profile, intrinsically related to precipitation events (Stenni et al., 2011), as a proxy of atmospheric pathways favourable for dust transport to Talos Dome from local sources; precipitation events do fulfil the necessary condition of being associated with airflow directed towards the interior of the continent, which in our conceptual model blows dust from the ice-free areas to Talos Dome. One possible limitation of this approach is that snow precipitation events may represent just one of the possible mechanisms responsible for local dust deposition at TALDICE, because dry deposition of dust may also occur. At present, no information is available on the relative proportions of dry and wet deposition of dust at Talos Dome.
While comparing the TALDICE and EDC dust flux in the $1-5 \mu \mathrm{m}$ size range (Fig. $4 \mathrm{~b}$ ) provides an appreciation of the additional contribution of local sources at Talos Dome, it is easier to evaluate the variability of local dust if we also consider the 5-10 $\mu \mathrm{m}$ size range (Fig. 3d), which we assume as derived entirely from proximal sources. Dust flux in both size ranges shows variations in correspondence with Termination I and the ACR. Yet, the very limited changes of dust flux in the 5-10 $\mu \mathrm{m}$ fraction (Fig. 3d) suggest that advection from Antarctic sources varied only slightly in relation to the major climate changes on the glacial-interglacial time scale. This is not the case for particle flux in the $1-5 \mu \mathrm{m}$ range (Fig. 3c), which includes a contribution from both remote and proximal sources. It is interesting to note that the relative dust minimum in TALDICE dust flux, at $\sim 13 \mathrm{kyr} \mathrm{BP}$, is evident in both size fractions (Fig. 3c, d). After this minimum, the dust flux in both size fractions increases again and shows large variability around relatively high values until 8$9 \mathrm{kyr}$ BP, when it starts to decline. The higher absolute values of the 5-10 $\mu \mathrm{m}$ fraction flux in the early Holocene compared to the relative minima at AIM1 and $13 \mathrm{kyr}$ BP suggest that the variable dust flux pattern between 13 and $9 \mathrm{kyr}$ BP could be related to the initial retreat of the Ross Ice Sheet (Fig. 1) in response to the deglaciation (Mackintosh et al., 2011). The associated formation of retreat moraine deposits made then available new potential dust sources, in addition to those already active during the glacial period. This hypothesis partially relies on the assumption that the reduction in the longterm local dust flux after Termination I is related to a weakening of local transport frequency/intensity. Similarly, we can explain the pronounced Holocene decreasing dust trend starting around $8 \mathrm{kyr} \mathrm{BP}$, observed in both size fractions (Fig. 3c, d) by considering two hypotheses: (1) the presence of local dust sources that underwent exhaustion during the Holocene or (2) changes in the atmospheric dust transport.

Based upon the hypothesis of an exhausting or reduced local source (formation of desert pavement on retreat moraine), a synchronous change in the dust grain size distribution, with an increasing $1-5 \mu \mathrm{m} / 5-10 \mu \mathrm{m}$ ratio would be expected as a consequence of the weakening of the local source(s). This is not supported by the data, as the $1-5 \mu \mathrm{m} / 5-10 \mu \mathrm{m}$ ratio (Fig. 3f) is variable, but rather constant after the deglaciation.

If we invoke changes in the transport of dust from local sources to Talos Dome to explain the Holocene decreasing trend in dust deposition, we should consider either (1) reduced frequency and/or intensity of maritime air mass advection related to the hypothetical long-term increase of katabatic winds, or (2) a long-term shift of the preferred trajectories of air masses on a climatological timescale, so that the potential source areas are subject to wind deflation to a lesser extent. Both hypotheses do not contradict the constraints posed by the observed dust size distributions, and they are not mutually exclusive. Nonetheless, there is evidence pointing to a possible change in atmospheric pathways during the middle and late Holocene. 
During the last glacial period, the presence of the Ross Ice Sheet affected the atmospheric circulation at a regional level i.e. among the air masses trajectories that today bring moisture to the Talos Dome site, those passing through the Ross Sea were then largely suppressed (Stenni et al., 2011). After the deglaciation, when most of the regional ice loss happened with the retreat and floating of the Ross Ice Sheet (Mackintosh et al., 2011), the opening of the Ross Sea embayment $\sim 8 \mathrm{kyr}$ BP marked the beginning of a new phase of retreat of the Ross Ice Shelf (Conway et al., 1999). The process continued (Baroni and Orombelli, 1991; Baroni and Hall, 2004), albeit with temporal and spatial variability (Hall et al., 2006), throughout the Holocene before a neoglacial re-advance during the last millennium (Hall, 2009). These events can indeed cause a consequent modification of the regional atmospheric circulation patterns, and the opening of the Ross Sea embayment appears to be coeval with the Holocene decreasing trend in dust flux at Talos Dome, evident in both the 1-5 $\mu \mathrm{m}$ and the $5-10 \mu \mathrm{m}$ size fractions. The TALDICE $\delta^{18} \mathrm{O}$ profile (Fig. 4a) records such variations: the weaker amplitude of AIM0 compared with other East Antarctic Plateau sites (e.g. Fig. 4a) indicates longer and cooler distillation pathways, compared to more direct trajectories from the Southern Ocean, which could occur by transit over the Ross Sea after the Ross Ice Sheet retreat (Stenni et al., 2011). In addition, the TALDICE $\delta^{18} \mathrm{O}$ profile (Fig. 3a) actually shows an increasing trend during the Holocene starting from $\sim 8 \mathrm{kyr} B P$ (Stenni et al., 2011; Masson-Delmotte et al., 2011), a signal that would be coherent with the progressively reduced ice cover in the Ross Sea embayment related to the retreat of the Ross Ice Shelf (Hall, 2009).

In this scenario, it appears that the change in the distribution of air masses trajectories - with those through the Ross Sea becoming relatively more frequent - is less favourable for the transport of local dust to the TALDICE site. We hypothesize that this may be linked to the higher effectiveness that the air masses coming from the Southern Ocean may have for blowing dust from the non-glaciated areas located at high altitude in Northern Victoria Land to Talos Dome. While explicatory hypotheses remain rather speculative at this stage, the possible explanation may reside in the geographical location of the local dust sources, with respect to the air masses trajectories, or may be linked to the spatial scale/intensity of air masses incursions.

If the assumption that the mechanism depicted above is substantially correct, it seems reasonable to find a relationship between the deglaciation history in the Ross Sea embayment and the decreasing trend of the TALDICE dust record during the Holocene. This scenario, which is based on documented changes in some key parameters relevant for the atmospheric circulation in the Ross Sea area, sets a framework for more extensive analyses aimed at deciphering, with more detail, the underlying mechanisms of the described changes, as well as their possible connections on shorter time scales.

\section{Conclusions}

The new dust record from the TALDICE ice core reflects both large-scale dust changes on glacial/interglacial time scales and a regional signal, emerging when dust advection from remote sources was extremely low. Dust deposition at Talos Dome reflects the major climate changes occurring on a hemispheric scale during the last climatic transition, as suggested by the first-order variability of dust in the 1-5 $\mu \mathrm{m}$ size range between 2 and $23 \mathrm{kyr}$ BP. However, the contribution from local dust sources makes Talos Dome sensitive to regional atmospheric circulation changes, in particular, during warm climate periods, such as the end of Termination I and the Holocene.

The relatively high and variable dust deposition at Talos Dome during the last stages of the deglaciation and the early Holocene may reflect the enhanced availability of dust originating from proximal sources, i.e. from glacial drift left behind from retreating glaciers during the initial phase of the retreat of the Ross Ice Sheet between 13 and 9 kyr BP. Afterwards, we suggest that the decreasing trend in dust deposition from $8 \mathrm{kyr}$ BP may be related to less favourable atmospheric transport from proximal dust sources, linked to the changes in atmospheric circulation, in response to the progressive opening of the Ross Sea embayment. Thus, we found a possible link between the deglaciation history of the Ross Sea and the mesoscale atmospheric circulation, which modulates the local dust flux at Talos Dome. Future extension of the TALDICE dust record to the last millennium will allow verification of the response of dust to the neo-glacial re-advance in the Ross Sea (Hall, 2009). In addition, future comparisons with other proxies such as marine aerosols and regional atmospheric modelling would help to further understand the atmospheric variability at the site.

Acknowledgements. The Talos Dome Ice core Project (TALDICE), a joint European programme, is funded by national contributions from Italy, France, Germany, Switzerland and the United Kingdom. Main logistic support was provided by PNRA. This is TALDICE publication no. 18. This work is a contribution to the PRIN 2009 research project "Variability and geographic provenance of eolian dust in Antarctica during the late Quaternary: a multi-parametric approach with the use of cutting-edge techniques". The HOLOCLIP Project, a joint research project of ESF PolarCLIMATE programme, is funded by national contributions from Italy, France, Germany, Spain, Netherlands, Belgium and the United Kingdom. In Italy HOLOCLIP is funded by PNRA. This is HOLOCLIP publication no. 8. We are grateful to A. Bory, S. Schüpbach and to H. Fischer for their constructive comments that helped to improve the manuscript. We also thank Yvette Wharton (University of Auckland) for her valuable comments to the English text. S. Albani acknowledges funding from "Dote Ricercatori": FSE, Regione Lombardia and the University of Milano-Bicocca for co-funding.

Edited by: H. Fischer 


\section{References}

Albani, S., Mahowald, N. M., Delmonte, B., Maggi, V., and Winckler, G.: Comparing modeled and observed changes in mineral dust transport and deposition to Antarctica between the Last Glacial Maximum and current climates, Clim. Dynam., online first: doi:10.1007/s00382-011-1139-5, 2011.

Baroni, C. and Hall, B. L.: A new Holocene relative sea-level curve for Terra Nova Bay, Victoria Land, Antarctica, J. Quaternary Sci., 19, 377-396, 2004.

Baroni, C. and Orombelli, G.: Holocene raised beaches at Terra Nova Bay, Victoria Land, Antarctica, Quaternary Res., 36, 157177, 1991.

Baroni, C., Frezzotti, M., Salvatore, M. C., Meneghel, M., Tabacco, I. E., Vittuari, L., Bondesan, A., Biasini, A., Cimbelli, A., and Orombelli, G.: Antarctic Geomorphological and Glaciological 1:250,000 map series. Mt. Murchison Quadrangle (northern Victoria Land). Explanatory notes. (with geomorphological map at the scale of 1:250.000), Ann. Glaciol., 39, 256-264, 2005.

Bory, A., Wolff, E., Mulvaney, R., Jagoutz, E., Wegner, A., Ruth, U., and Elderfield, H.: Multiple sources supply eolian mineral dust to the Atlantic sector of coastal Antarctica: Evidence from recent snow layers at the top of Berkner Island ice sheet, Earth Planet. Sc. Lett., 291, 138-148, 2010.

Buiron, D., Chappellaz, J., Stenni, B., Frezzotti, M., Baumgartner, M., Capron, E., Landais, A., Lemieux-Dudon, B., MassonDelmotte, V., Montagnat, M., Parrenin, F., and Schilt, A.: TALDICE-1 age scale of the Talos Dome deep ice core, East Antarctica, Clim. Past, 7, 1-16, doi:10.5194/cp-7-1-2011, 2011.

Carrasco, J. F., Bromwich, D. H., and Monaghan, A. J.: Distribution and characteristics of mesoscale cyclones in the Antarctic: Ross Seas Eastward to the Weddell Sea, Mon. Weather Rev., 131, 289301, 2003.

Conway, H., Hall, B. L., Denton, G. H., Gades, A. M., and Waddington, E. D.: Past and future grounding-line retreat of the Western Antarctic Ice Sheet, Science, 286, 280-283, 1999.

Delmonte, B., Petit, J.-R., Andersen, K. K., Basile-Doelsch, I., Maggi, V., and Ya Lipenkov, V.: Dust size evidence for opposite regional atmospheric circulation changes over east Antarctica during the last climatic transition, Clim. Dynam., 23, 427438, 2004.

Delmonte, B., Petit, J.-R., Krinner, G., Maggi, V., Jouzel, J., and Udisti, R.: Ice core evidence for secular variability and 200-year dipolar oscillations in atmospheric circulation over East Antarctica during the Holocene, Clim. Dynam., 24, 641-654, 2005.

Delmonte, B., Andersson, P. S., Hansson, M., Schöberg, H., Petit, J.-R., Basile-Doelsch, I., and Maggi, V.: Aeolian dust in East Antarctica (EPICA-Dome C and Vostok): Provenance during glacial ages over the last 800 kyr, Geophys. Res. Lett., 35, L07703, doi:10.1029/2008GL033382, 2008.

Delmonte, B., Andersson, P. S., Schöberg, H., Hansson, M., Petit, J.-R., Delmas, R., Gaiero, D. M., Maggi, V., and Frezzotti, M.: Geographic provenance of aeolian dust in East Antarctica during Pleistocene glaciations: preliminary results from Talos Dome and comparison with East Antarctic and new Andean ice core data, Quaternary Sci. Rev., 29, 256-264, 2010a.

Delmonte, B., Baroni, C., Andersson, P. S., Schöberg, H., Hansson, M., Aciego, S., Petit, J.-R., Albani, S., Mazzola, C., Maggi, V., and Frezzotti, M.: Aeolian dust in the Talos Dome ice core (East Antarctica, Pacific/Ross Sea sector): Victoria Land versus remote sources over the last two climate cycles, J. Quaternary Sci., 25, 1327-1337, 2010b.

Delmonte, B., Andersson, P. S., Baroni, C., Narcisi, B., Petit, J. R., Salvatore, M. C., Albani, S., and Maggi, V.: Holocene regional gradients of dust provenance and flux between Talos Dome and Dome C, East Antarctica, Geophys. Res. Abstr., EGU20121293-3, EGU General Assembly 2012, Vienna, Austria, 2012.

EPICA Community Members: Eight glacial cycles from an Antarctic ice core, Nature, 429, 623-628, 2004.

Fuhrer, K., Wolff, E. W., and Johnsen, S. J.: Timescales for dust variability in the Greenland Ice Core Project (GRIP) ice core in the last 100,000 years, J. Geophys. Res., 104, 31043-31052, 1999.

Hall, B. L.: Holocene glacial history of Antarctica and the subAntarctic islands, Quaternary Sci. Rev., 28, 2213-2230, 2009.

Hall, B. L., Hoelzel, A. R., Baroni, C., Denton, G. H., Le Boeuf, B. J., Overturf, J., and Töpf, A. L.: Holocene elephant seal distribution implies warmer-than-present climate in the Ross Sea, P. Natl. Acad. Sci. USA, 103, 10213-10217, 2006.

IPCC: Climate Change 2007: The Physical Science Basis. Contribution of Working Group I to the Fourth Assessment Report of the Intergovernmental Panel on Climate Change, edited by: Solomon, S., Qin, D., Manning, M., Chen, Z., Marquis, M., Averyt, K. B., Tignor, M., and Miller, H. L., Cambridge University Press, Cambridge, United Kingdom and New York, NY, USA, 996 pp., 2007.

Kohfeld, K. E. and Harrison, S. P.: DIRTMAP: the geological record of dust, Earth-Sci. Rev., 54, 81-114, 2001.

Krinner, G., Petit, J.-R., and Delmonte, B.: Altitude of atmospheric tracer transport towards Antarctica in present and glacial climate, Quaternary Sci. Rev., 29, 274-284, 2010.

Lambert, F., Delmonte, B., Petit, J.-R., Bigler, M., Kaufmann, P. R., Hutterli, M. A., Stocker, T. F., Ruth, U., Steffensen, J. P., and Maggi, V.: Dust-climate couplings over the past 800,000 years from the EPICA Dome C ice core, Nature, 452, 616-619, 2008.

Lemieux-Dudon, B., Blayo, E., Petit, J.-R., Waelbroeck, C., Svensson, A., Ritz, C., Barnola, J. M., Narcisi, B. M., and Parrenin, F.: Consistent dating for Antarctic and Greenland ice cores, Quaternary Sci. Rev., 29, 8-20, 2010.

Li, F., Ginoux, P., and Ramaswamy, V.: Distribution, transport, and deposition of mineral dust in the Southern Ocean and Antarctica: Contribution of major sources, J. Geophys. Res., 113, D10207, doi:10.1029/2007JD009190, 2008.

Mackintosh, A., Golledge, N., Domack, E., Dunbar, R., Leventer, A., White, D., Pollard, D., DeConto, R., Fink, D., Zwartz, D., Gore, D., and Lavoie, C.: Retreat of the East Antarctic ice sheet during the last glacial termination, Nat. Geosci., 4, 195202, 2011.

Mahowald, N. M., Albani, S., Engelstaedter, S., Winckler, G., and Goman, M.: Model insight into glacial-interglacial paleodust records, Quaternary Sci. Rev., 30, 832-854, 2010.

Masson-Delmotte, V., Buiron, D., Ekaykin, A., Frezzotti, M., Gallée, H., Jouzel, J., Krinner, G., Landais, A., Motoyama, H., Oerter, H., Pol, K., Pollard, D., Ritz, C., Schlosser, E., Sime, L. C., Sodemann, H., Stenni, B., Uemura, R., and Vimeux, F.: A comparison of the present and last interglacial periods in six Antarctic ice cores, Clim. Past, 7, 397-423, doi:10.5194/cp-7397-2011, 2011.

Narcisi, B., Petit, J.-R., and Chappellaz, J.: A 70 ka record of ex- 
plosive eruptions from the TALDICE ice core (Talos Dome, East Antarctic plateau), J. Quaternary Sci., 25, 844-849, 2010.

Petit, J.-R., Jouzel, J., Raynaud, D., Barkov, N. I., Barnola, J. M., Basile, I., Bender, M., Chappellaz, J., Davisk, M., Delaygue, G., Delmotte, M., Kotlyakov, V. M., Legrand, M., Lipenkov, V. Y., Lorius, C., Pepin, L., Ritz, C., Saltzman, E., and Stievenard, M.: Climate and atmospheric history of the past 420,000 years from the Vostok ice core, Antarctica, Nature, 399, 429-436, 1999.

Prospero, J. M., Ginoux, P., Torres, O., Nicholson, S. E., and Gill, T. E.: Environmental characterization of global sources of atmospheric soil dust identified with the Nimbus 7 Total Ozone mapping spectrometer (TOMS) Absorbing Aerosol Product, Rev. Geophys., 40, 1002, doi:10.1029/2000RG000095, 2002.

Sala, M., Delmonte, B., Frezzotti, M., Proposito, M., Scarchilli, C., Maggi, V., Artioli, G., Dapiaggi, M., Marino, F., Ricci, P. C., and De Giudici, G.: Evidence of calcium carbonates in coastal (Talos Dome and Ross Sea area) East Antarctica snow and firn: Environmental and climatic implications, Earth Planet Sc. Lett., 271, 43-52, 2008.

Scarchilli, C., Frezzotti, M., and Ruti, P. M.: Snow precipitation at four ice core sites in East Antartica: provenance, seasonality and blocking factors, Clim. Dynam., 37, 2107-2125, 2011.

Steffensen, J. P., Andersen, K. K., Bigler, M., Clausen, H. B., DahlJensen, D., Fischer, H., Goto-Azuma, K., Hansson, M., Johnsen, S. J., Jouzel, J., Masson-Delmotte, V., Popp, T., Rasmussen, S. O., Röthlisberger, R., Ruth, U., Stauffer, B., Siggaard-Andersen, M. L., Sveinbjörnsdóttir, A. E., Svensson, A., and White, J. W. C.: High-resolution Greenland ice core data show abrupt climate change happens in few years, Science, 321, 680-684, 2008.
Stenni, B., Masson-Delmotte, V., Selmo, E., Oerter, H., Meyer, H., Röthlisberger, R., Jouzel, J., Cattani, O., Falourd, S., Fischer, H., Hoffmann, G., Iacumin, P., Johnsen, S. J., Minster, B., and Udisti, R.: The deuterium excess records of EPICA Dome $\mathrm{C}$ and Dronning Maud Land ice cores (East Antarctica), Quaternary Sci. Rev., 29, 146-159, 2010.

Stenni, B., Buiron, D., Frezzotti, M., Albani, S., Barbante, C., Bard, E., Barnola, J. M., Baroni, M., Baumgartner, M., Bonazza, M., Capron, E., Castellano, E., Chappellaz, J., Delmonte, B., Falourd, S., Genoni, L., Iacumin, P., Jouzel, J., Kipfstuhl, S., Landais, A., Lemieux-Dudon, B., Maggi, V., Masson-Delmotte, V., Mazzola, C., Minster, B., Montagnat, M., Mulvaney, R., Narcisi, B., Oerter, H., Parrenin, F., Petit, J. R., Ritz, C., Scarchilli, C., Schilt, A., Schüpbach, S., Schwander, J., Selmo, E., Severi, M., Stocker, T. F., and Udisti, R.: Expression of the bipolar seesaw in Antarctic climate records during the last deglaciation, Nat. Geosci., 4, 46-49, doi:10.1038/ngeo1026, 2011.

Thompson, L. G., Mosley-Thompson, E., Davis, M. E., Lin, P. N., Henderson, K. A., Cole-Dai, J., Bolzan, J. F., and Liu, K. B.: Late-glacial stage and Holocene tropical ice core records from Huascarán, Peru, Science, 269, 46-50, 1995.

Xu, J., Hou, S., Qin, D., Kaspari, S., Mayewski, P. A., Petit, J.-R., Delmonte, B., Kang, S., Ren, J., Chappellaz, J., and Hong, S.: A 108.83-m ice-core record of atmospheric dust deposition at Mt. Qomolangma (Everest), Central Himalaya, Quaternary Res., 73, 33-38, 2010. 